\title{
Breast cancer: Metronomic therapy focused on muscarinic acetylcholine receptors
}

\author{
María Elena Sales* \\ Centro de Estudios Farmacológicos y Botánicos (CEFYBO)-CONICET, 2da Cátedra de Farmacología, Facultad de Medicina, Argentina
}

\section{Muscarinic receptors in breast cancer}

Muscarinic acetylcholine receptors (mAChRs) belong to the $\mathrm{G}$ protein coupled receptor group (GPCRs) and together with nicotinic receptors formed the cholinergic receptor family [1]. Both types of receptors respond to acetylcholine but trigger different signaling pathways since the first one exerts metabotropic actions while the latter is ionotropic. Several authors reported the expression of $m A C h R s$ in tumor cells and tissues [2]. Five subtypes of mAChRs $\left(M_{1}-M_{5}\right)$ have been cloned. Their activation by acetylcholine triggers not only the activation of classical signal transduction pathways like phospholipase C/inositol trisphophate/calcium for M1, M3 and M5 subtypes and the inhibition of adenylyl cyclase for M2 and M4 subtypes; but may activate also non-canonical signals like Ras-Raf-1-Erk-AKT for M3 receptor subtype $[1,3]$.

We described, for the first time the presence of different subtypes of mAChRs in murine and human breast tumors. The five subtypes of $\mathrm{mAChRs}$ are expressed in three different mammary tumors (LM2, LM3 and LMM3) that spontaneously aroused in BALB/c mice, but they are absent in normal murine mammary epithelial cells (NMuMG) [4-6]. Meanwhile, the pattern of expression of mAChRs in human mammary breast tumors differs depending on the cell line analyzed. MCF-7 cells express $M_{3}$ and $M_{4}$ receptor subtypes while MDA-MB231 cells exhibit $M_{1}, M_{2}, M_{4}$ and $M_{5}$ receptors expression [7,8]. Similarly to that observed in mice, mAChRs were not detected in the human non-tumorigenic mammary cell line, MCF-10A. Preliminary results from our laboratory demonstrate that the transfection of MCF-10A cell with $\mathrm{mAChRs}$ induces the malignant transformation promoting three dimensional growth in vitro and angiogenesis and tumor generation in nude mice [9].

We also reported that the activation of mAChRs with the synthetic non-degradable agonist carbachol, for short periods of time stimulates tumor cell proliferation via different metabolic pathways [10]. In MCF-7 cells, the stimulatory action of carbachol on cell proliferation was mediated mainly by $\mathrm{M}_{3}$ receptor inactivation that triggers phospholipase C/nitric oxide synthase (NOS) pathway [7].

On the contrary, the addition of the agonist for longer periods of time reduced cell viability either in mice or in human tumor breast cell lines $[11,12]$. The latter was also reported for the treatment of brain tumor cells with the selective $M_{2}$ receptor agonist arecaidine propargyl ester (APE) [13].

\section{Muscarinics as repurposing drugs in metronomic therapy \\ The results mentioned above indicate that muscarinic agonists may act as anti-tumor drugs, and should be considered as repositioning drugs. The latter refers to the assignation of new uses for existing drugs}

and represents an alternative drug development strategy. In oncology, there is an increasing interest in the prescription of non-cancer drugs for cancer treatments due to the knowledge of pharmacokinetics/ dynamics, side effects, and because most of them are available at low cost [14]. Many repurposing drugs have been studied to be used in breast cancer treatment: $\beta 2$ adrenergic receptor blockers [15], the anti-diabetic drug metformin [16] or the PPR $\gamma$-ligand, pioglitazone [17]. Another important aspect of chemotherapy in cancer treatment is its schedule of administration. Traditional chemotherapy is based on the usage of cytotoxic/cytostatic drugs administered at maximal tolerable dose in order to kill as much tumor cells as possible, although as it is well known this treatment causes severe side effects. Based on this background Hanahan et al. in 2000 devised a different way of administering chemotherapy named metronomic therapy (MT) [18]. The term MT was used by Hanahan referring to the "close, regular administration of a chemotherapeutic drug for a long time with no extended drug-free breaks" [18]. It should be useful as a strategy to break resistance to drug treatment and also to target the tumor vasculature besides the tumor cells. Phase II/III studies for the treatment of triple negative breast cancer patients are currently being developed with encouraging results $[19,20]$. MT is not only applied with traditional drugs alone but also combined with repurposing drugs. Roy et al., [21] have recently demonstrated that the addition of suboptimal concentrations of the glycolytic metabolite, methylglyoxal in a combination regimen with traditional chemotherapeutic drugs against breast cancer like doxorubicin or cisplatin at metronomic concentrations produces a synergistic increment in doxorubicin and cisplatin mediated cytotoxicity in human breast cancer cell lines MDAMB231 or MCF-7. This treatment promoted apoptosis or necroptosis in tumor cells respectively and also reduced breast cancer stem cells in both cell lines [21].

In our laboratory we, designed a combination of the muscarinic agonist carbachol plus the chemotherapeutic agent paclitaxel, usually administered for breast cancer treatment scheduled as MT. The administration of carbachol plus paclitaxel at sub threshold concentrations induced MCF-7 cell death by up-regulating NOS3 expression and reducing arginase II activity [12]. This kind of treatment also reduced de percentage of cancer stem cells (CD44+/CD24-) in MCF-7 cells [22]. This result could be advantageous to prevent tumor

*Correspondence to: María Elena Sales, Centro de Estudios Farmacológicos y Botánicos (CEFYBO)-CONICET. 2da Cátedra de Farmacología. Facultad de Medicina, UBA, Argentina, E-mail: malegazpio@yahoo.com.ar

Received: October 02, 2018; Accepted: October 20, 2018; Published: October 24,2018 
metastasis and recidivas. In addition, we observed that this metronomic combination was also effective on MDA-MB231 cells and on murine breast cancer cells promoting more apoptosis than necrosis [11]. Moreover, we observed that if paclitaxel is replaced by doxorubicin in the combination, a significant cytotoxic effect is also obtained on both MCF-7 and MDA-MB231 cells (unpublished results). Further in vitro and in vivo studies should be done to demonstrate beneficial effects of MT focused on mAChRs in pre-clinical studies for further insurance positive effects on breast cancer patients.

\section{References}

1. van Koppen CJ, Kaiser B (2003) Regulation of muscarinic acetylcholine receptor signaling. Pharmacol Ther 98: 197-220. [Crossref]

2. Paleari L1, Grozio A, Cesario A, Russo P (2008) The cholinergic system and cancer. Semin Cancer Biol 18: 211-217. [Crossref]

3. Russo P, Del Bufalo A, Milic M, Salinaro G, Fini M, et al. (2014) Cholinergic receptors as target for cancer therapy in a systems medicine perspective. Curr Mol Med 14: 11261138. [Crossref]

4. Español AJ, Sales ME (2004) Different muscarinc receptors are involved in the proliferation of murine mammary adenocarcinoma cell lines. Int J Mol Med 13: 311319. [Crossref]

5. Español A, Eiján AM, Mazzoni E, Davel L, Jasnis MA, et al. (2002) Nitric oxide synthase, arginase and cyclooxygenase are involved in muscarinic receptor activation in different murine mammary adenocarcinoma cell lines. Int J Mol Med 9: 651-657. [Crossref]

6. Rimmaudo LE, de la Torre E, Sacerdote de Lustig E, Sales ME (2005) Muscarinic receptors are involved in LMM3 tumor cells proliferation and angiogenesis. Biochem Biophys Res Commun 334: 1359-1364. [Crossref]

7. Fiszman GL, Middonno MC, de la Torre E, Farina M, Español AJ, et al. (2007) Activation of muscarinic cholinergic receptors induces MCF-7 cells proliferation and angiogenesis by stimulating nitric oxide synthase activity. Cancer Biol Ther 6: 11061113. [Crossref]

8. Salem A, Sanchez Y, Sales ME, Español A (2017) Anti-tumor actions of paclitaxel plus carbachol on human triple negative breast cancer cells. Medicina 77 (Supl I): 254.

9. Martinez Pulido P, Lombardi MG, Sales ME (2017) Muscarinic receptors in nontumorigenic MCF-10A breast cells. Effect of carbachol on three-dimensional growth and VEGF-A expression. Medicina 77 (Supl I): 363.
10. Español AJ, de la Torre E, Fiszman GL, Sales ME (2007) Role of non-neuronal cholinergic system in breast cancer progression. Life Sci 80: 2281-2285. [Crossref]

11. Español AJ, Jacob G, Dmytrenko G, Sales ME (2013) Muscarinic activation enhances the anti-proliferative effect of paclitaxel in murine breast tumor cells. Anticancer Agents Med Chem 13: 1273-1279. [Crossref]

12. Español AJ, Salem A, Rojo D, Sales ME (2015) Participation of non-neuronal muscarinic receptors in the effect of carbachol with paclitaxel on human breast adenocarcinoma cells. Roles of nitric oxide synthase and arginase. Int Immunopharmacol 29: 87-92. [Crossref]

13. Alessandrini F, Cristofaro I, Di Bari M, Zasso J, Conti L, et al. (2015) The activation of M2 muscarinic receptor inhibits cell growth and survival in human glioblastoma cancer stem cells. Int Immunopharmacol 29: 105-109. [Crossref]

14. Pantziarka P, Bouche G, Meheus L, Sukhatme V, Sukhatme VP (2015) Repurposing drugs in your medicine cabinet: untapped opportunities for cancer therapy? Future Oncol 11: 181-184. [Crossref]

15. Choy C, Raytis JL, Smith DD, Duenas M, Neman J, et al. (2016) Inhibition of B2adrenergic receptor reduces triple-negative breast cancer brain metastases: The potential benefit of perioperative ß-blockade. Oncol Rep 35: 3135-3142. [Crossref]

16. Gadducci A, Biglia N, Tana R, Cosio S, Gallo M (2016) Metformin use and gynecological cancers: A novel treatment option emerging from drug repositioning. Crit Rev Oncol Hematol 105: 73-83. [Crossref]

17. Papi A, De Carolis S, Bertoni S, Storci G, Sceberras V, et al. (2014) PPAR $\hat{I}^{3}$ and RXR ligands disrupt the inflammatory cross-talk in the hypoxic breast cancer stem cells niche. J Cell Physiol 229: 1595-1606. [Crossref]

18. Hanahan D, Bergers G, Bergsland E (2000) Less is more, regularly: metronomic dosing of cytotoxic drugs can target tumor angiogenesis in mice. J Clin Invest 105: 1045-1047. [Crossref]

19. Munzone E, Colleoni M (2015) Clinical overview of metronomic chemotherapy in breast cancer. Nat Rev Clin Oncol 12: 631-644. [Crossref]

20. Cazzaniga ME, Dionisio MR, Riva F (2017) Metronomic chemotherapy for advanced breast cancer patients. Cancer Lett 400: 252-258.

21. Roy A, Sarker S, Upadhyay P, Pal A, Adhikary A, et al. (2018) Methylglyoxal at metronomic doses sensitizes breast cancer cells to doxorubicin and cisplatin causing synergistic induction of programmed cell death and inhibition of stemness. Biochem Pharmacol 156: 322-339. [Crossref]

22. Salem A, Sanchez Y, Laserna L, Williams M, Español A, et al. (2017) Benefits of metronomic therapy targeting muscarinic receptors in breast cancer as a sensitizer of cells to classic chemotherapy with paclitaxel. Medicina 77 (Supl I): 415.

Copyright: (C2018 Sales ME. This is an open-access article distributed under the terms of the Creative Commons Attribution License, which permits unrestricted use, distribution, and reproduction in any medium, provided the original author and source are credited. 